\title{
Pengendalian Gulma pada Tanaman Padi Sawah dengan Menggunakan Herbisida Berbahan Aktif Campuran Bentazon dan MCPA
}

\author{
Weed Control in rice with Bentazon and MCPA as Mixed Herbicide
}

\author{
Seken Polansky dan Dwi Guntoro*
}

\author{
Departemen Agronomi dan Hortikultura, Fakultas Pertanian, Institut Pertanian Bogor \\ (Bogor Agricultural University), Jl. Meranti, Kampus IPB Darmaga, Bogor 16680, Indonesia \\ Telp. \& Faks. 62-251-8629353 e-mail agronipb@indo.net.id \\ *Penulis untuk korespondensi: dwiguntoro@yahoo.com
}

Disetujui tanggal 18 Januari 2016 / Published online 25 Januari 2016

\begin{abstract}
Weeds are one of major problem in rice production. The objective of this research was to observe the effectiveness of bentazon and MCPA as mixed herbicide to control weeds in rice field. The experiment was conducted at Bojong Jengkol village, Ciampea sub district, Bogor, West Java from September 2012 until January 2013. This research was arranged in Randomized Block Design with single factor, seven treatments and four replications. The treatments consist of seven treatments with five dosages of herbicide (i.e.: $1.00 \mathrm{~L}$ $\mathrm{ha}^{-1}, 1.50 \mathrm{~L} \mathrm{ha}^{-1}, 2.00 \mathrm{~L} \mathrm{ha}^{-1}, 2.50 \mathrm{~L} \mathrm{ha}^{-1}$, and $3.00 \mathrm{~L} \mathrm{ha}^{-1}$ ), conventional weeding (at third and sixth week after transplanted) and no weeding. The result showed that bentazon-MCPA application could control sedges (Fimbristylis miliacea and Cyperus iria) and broadleaf (Ludwigia octovalvis, Alternanthera philoxeroides, and Portulaca oleracea) weeds. Application of bentazon-MCPA caused light-fair toxicity symptomps on rice plants until 2 weeks after application and decreased empty grain percentage by about 6$10 \%$ as compared with no weeding treatment. The aplication also increased rice yield by about 48.6\%; how ever it and that was not significantly different to conventional weeding.
\end{abstract}

Keywords: Bentazon-MCPA, weed control, weed in rice

\begin{abstract}
ABSTRAK
Gulma merupakan salah satu kendala utama dalam produksi padi sawah. Penelitian ini bertujuan untuk mengetahui efektivitas herbisida berbahan aktif campuran bentazon dan MCPA untuk mengendalikan gulma padi sawah. Percobaan dilaksanakan di Desa Bojong Jengkol, Kecamatan Ciampea, Kabupaten Bogor, Jawa Barat dari September 2012 hingga Januari 2013. Percobaan menggunakan Rancangan Acak Kelompok satu faktor dengan tujuh perlakuan dan empat ulangan. Percobaan terdiri atas 5 perlakuan herbisida berbahan aktif bentazon dan MCPA yaitu dosis $1.00 \mathrm{~L} \mathrm{ha}^{-1}, 1.50 \mathrm{~L} \mathrm{ha}^{-1}, 2.00 \mathrm{~L} \mathrm{ha}^{-1}$, 2.50 L ha , $3.00 \mathrm{~L} \mathrm{ha}^{-1}$; pengendalian gulma manual dan tanpa pengendalian gulma (kontrol). Hasil menunjukkan aplikasi herbisida berbahan aktif campuran bentazon dan MCPA dapat mengendalikan gulma dari golongan teki dan gulma daun lebar. Spesies gulma yang terkendalikan dari golongan teki adalah Fimbristylis miliacea dan Cyperus iria, sedangkan dari golongan daun lebar adalah Ludwigia octovalvis, Alternanthera philoxeroides, dan Portulaca oleracea. Aplikasi herbisida pada semua dosis uji menunjukkan toksisitas rendah pada tanaman padi. Aplikasi herbisida berbahan aktif Bentazon dan MCPA pada semua dosis uji menurunkan persentase gabah hampa sebesar 6-10\% serta dapat meningkatkan produktivitas padi sebesar $48.6 \%$ yang tidak berbeda dengan produktivitas padi pada pengendalian manual.
\end{abstract}

Kata kunci : Bentazon-MCPA, gulma padi sawah, pengendalian gulma 


\section{PENDAHULUAN}

Seiring dengan bertambahnya jumlah penduduk Indonesia tiap tahunnya kebutuhan beras nasional akan ikut naik. Berdasarkan data BPS hingga tahun 2013 tentang produksi padi, kebutuhan beras nasional meningkat dari $139 \mathrm{~kg}$ per kapita pada tahun 2011 menjadi $145 \mathrm{~kg}$ per kapita walaupun produksi beras pada 2013 surplus 5.4 juta ton. Menyikapi hal tersebut perlu adanya usaha peningkatan produksi padi untuk mencapai ketahanan pangan nasional dan tidak terjadi impor.

Tingginya konversi lahan sawah menjadi lahan non pertanian menjadi salah satu masalah peningkatan produksi pangan Indonesia (Agus, 2011). Menghadapi masalah ini perlu pengusahaan peningkatan hasil yang lebih efisien dan efektif. Bintari (2006) dan Suhartini (2010) mengungkapkan peningkatan produksi padi dapat dilakukan dengan penanaman padi hibrida yang memiliki produktivitas yang lebih tinggi jika dibandingkan dengan padi inbrida.

Penurunan jumlah tenaga kerja pertanian juga menjadi kendala terkait ketersediaan tenaga kerja pengendalian gulma secara manual. Menurut data BPS tahun 2012, ketenagakerjaan di sektor pertanian mengalami penurunan jumlah tenaga kerja yang cukup signifikan tiap tahunnya. Penurunan tenaga kerja terbesar pada periode agustus 2010 hingga 2011 sebesar satu juta tenaga kerja. Hamid (2004) melaporkan bahwa penggunaan pola tanam padi dengan populasi tinggi mampu menekan keberadaan gulma. Namun penggunaan metode tersebut tidak efisien. Penelitian Makarim dan Ikhwani (2010) menyatakan bahwa peningkatan populasi pertanaman padi tidak menunjukkan hasil yang sebanding terhadap produktivitas padi per hektar. Oleh karena itu perlu dilakukannya metode pengendalian gulma yang lebih efisien.

Pengendalian gulma padi sawah menggunakan bahan aktif bentazon sudah umum dilakukan di negara dengan tenaga kerja pertanian yang minim seperti Australia dan Selandia baru. Penggunaan herbisida bentazon dilaporkan efektif untuk mengendalikan gulma teki dan daun lebar apabila ditambahkan bahan aktif MCPA/B (AGPRO, 2013). Pengendalian gulma menggunakan herbisida di Indonesia sendiri sudah umum dilakukan pada lahan perkebunan namun belum umum digunakan untuk mengendalikan gulma padi sawah. Penelitian bertujuan untuk mengetahui pengaruh dan efektivitas aplikasi herbisida berbahan aktif campuran bentazon dan
MCPA untuk mengendalikan gulma pada tanaman padi sawah.

\section{BAHAN DAN METODE}

Penelitian dilaksanakan di lahan sawah Desa Bojong Jengkol, Ciampea, Kab. Bogor, Jawa Barat pada bulan September 2012 hingga Januari 2013. Bahan-bahan yang digunakan antara lain benih padi varietas Ciherang, pupuk Urea, pupuk NPK Phonska 15-15-15, pupuk KCl, Furadan 3G, herbisida berbahan aktif campuran bentazon $(400$ $\left.\mathrm{g} \mathrm{L}^{-1}\right)$ dan MCPA $\left(60 \mathrm{~g} \mathrm{~L}^{-1}\right)$, insektisida-fungisida Antracol 70 WP, bakterisida Regent 50 EC, dan air. Alat yang akan digunakan antara lain: knapsack sprayer, nozzle T-jet biru, gelas ukur, ember, timbangan analitik, oven, dan alat bagan warna daun (BWD).

Penelitian menggunakan Rancangan Acak Kelompok (RAK) dengan satu faktor yang terdiri atas tujuh perlakuan dan empat ulangan. Satuan percobaan berukuran $4 \mathrm{~m} \times 5 \mathrm{~m}$. Jumlah satuan percobaan adalah 28 satuan. Ketujuh perlakuan tersebut adalah dosis aplikasi herbisida Bentazon dan MCPA 1.00 $\mathrm{L} \mathrm{ha}^{-1}, 1.50 \mathrm{~L} \mathrm{ha}^{-1}, 2.00 \mathrm{~L} \mathrm{ha}^{-1}$, $2.50 \mathrm{~L} \mathrm{ha}^{-1}$, dan $3.00 \mathrm{~L} \mathrm{ha}^{-1}$, pengendalian gulma manual dan tanpa pengendalian gulma sebagai kontrol. Data dianalisis menggunakan analisis ragam (Uji F) dan dilanjutkan dengan uji lanjut Duncan Multiple Range Test (DMRT) pada taraf $5 \%$.

Pengolahan tanah dilakukan dengan pembajakan sebanyak satu kali. Pindah tanam dilakukan saat bibit berumur 21 hari setelah semai dengan jarak tanam $30 \mathrm{~cm} \times 15 \mathrm{~cm}$. Pemupukan dilakukan dengan dosis $200 \mathrm{~kg} \mathrm{ha}^{-1}$ urea, $100 \mathrm{~kg}$ $\mathrm{ha}^{-1} \mathrm{KCL}$ dan $400 \mathrm{~kg} \mathrm{ha}^{-1}$ NPK phonska masingmasing 50\% dosis pada umur 1 dan 4 minggu setelah pindah tanam (MST). Pemeliharaan dilakukan meliputi penyulaman bibit, pengairan, pengendalian hama dan penyakit. Pengendalian hama dan penyakit dilakukan dengan penebaran Furadan 3G dengan dosis $20 \mathrm{~kg} \mathrm{ha}^{-1}$ dan menyemprotkan insektisida berbahan aktif Fipronil $50 \mathrm{~g} \mathrm{~L}^{-1}$ dengan merk dagang Regent 50 SC dan fungisida berbahan aktif Probineb 70\% dengan merk dagang Antracol 70 WP. Panen dilakukan pada umur 96 hari setelah tanam (HST). Aplikasi perlakuan dosis herbisida dilakukan pada umur 9 hari setelah pindah tanam dengan volume semprot $400 \mathrm{~L} \mathrm{ha}^{-1}$. Perlakuan pengendalian manual tanaman padi dilakukan sebanyak dua kali pada umur 3 MST dan 6 MST.

Pengamatan gulma dilakukan setiap 2 minggu setelah aplikasi (MSA) sebanyak 4 kali pengamatan pada masing-masing petak perlakuan 
dan menggunakan kuadran $0.25 \mathrm{~m}^{2}$. Peubah yang diamati antara lain: bobot kering gulma sasaran total dan per spesies, jumlah gulma per spesies, fitotoksisitas herbisida terhadap padi, tinggi tanaman, jumlah anakan padi, biomassa rumpun padi, nisbah tajuk dan akar, Indeks Luas Daun (ILD), panjang akar brangkasan padi, jumlah bulir per malai, persentase gabah isi dan hampa per malai, bobot 1000 butir, bobot gabah kering panen (GKP) dan gabah kering giling (GKG).

\section{HASIL DAN PEMBAHASAN}

\section{Keadaan Umum}

Lahan penelitian berada pada ketinggian sekitar 280 meter di atas permukaan laut (mdpl) dengan rata-rata curah hujan dan intensitas cahaya bulan September 2012 hingga Januari 2013 berturut-turut sebesar $490.8 \mathrm{~mm}$ dan 342.0 $\mathrm{Cal} / \mathrm{cm}^{2}$. Selama percobaan berlangsung rata-rata suhu harian berada pada $25.7{ }^{\circ} \mathrm{C}$ dengan kelembaban udara rata-rata $83 \%$ (BMKG 2013).

Hama yang ditemukan selama percobaan adalah keong sawah (Pomacea canaliculata Lamarck) dan walang sangit (Leptocorisa acuta). Hama keong menyerang tanaman padi selama sejak pindah tanam hingga umur 3 MST. Penanggulangan hama keong dilakukan dengan pengambilan manual. Hama walang sangit pada lahan muncul pada umur vegetatif 6 MST. Penyakit kresek atau hawar daun oleh Xanthomonas oryzae padi terjadi pada umur 6 MST menyerang seluruh tanaman padi di lahan percobaan. Penyakit hawar daun menyebabkan kematian satu hingga dua anakan tanaman padi pada seluruh satuan percobaan. Penanggulangan hama dan penyakit padi dilakukan dengan penyemprotan pestisida berbahan aktif Fipronil 50 g $\mathrm{L}^{-1}$ dan Probineb $70 \%$ dengan konsentrasi aplikasi berturut-turut $0.55 \mathrm{~L} \mathrm{ha}^{-1}$ dan $1.25 \mathrm{~L} \mathrm{ha}^{-1}$. Penyemprotan pestisida dilakukan pada umur 6 MST setiap tiga hari sekali selama dua minggu hingga tanaman padi terlihat kembali menghijau dengan volume semprot $300 \mathrm{~L} \mathrm{ha}^{-1}$.

\section{Bobot Kering Gulma Sasaran Total}

Aplikasi herbisida berbahan aktif campuran bentazon dan MCPA berpengaruh terhadap biomassa gulma total sasaran pada lahan percobaan sejak 2 MSA hingga umur 8 MSA pada semua dosis uji dibandingkan dengan perlakuan kontrol. Aplikasi herbisida berbahan aktif campuran bentazon dan MCPA pada semua dosis uji menunjukkan pengaruh pengendalian biomassa gulma yang tidak berbeda nyata dibandingkan terhadap perlakuan pengendalian manual (Tabel $1)$.

Tabel 1. Pengaruh aplikasi herbisida campuran bentazon dan MCPA terhadap biomassa gulma sasaran total

\begin{tabular}{|c|c|c|c|c|c|}
\hline Perlakuan & Dosis & $2 \mathrm{MSA}$ & $4 \mathrm{MSA}$ & $6 \mathrm{MSA}$ & $8 \mathrm{MSA}$ \\
\hline & & ………. & ................. & & \\
\hline Bentazon/MCPA & $1.00 \mathrm{~L} \mathrm{ha}^{-1}$ & $0.322 \mathrm{~b}$ & $1.023 \mathrm{~b}$ & $0.276 \mathrm{~b}$ & $1.166 \mathrm{~b}$ \\
\hline Bentazon/MCPA & $1.50 \mathrm{~L} \mathrm{ha}^{-1}$ & $0.226 \mathrm{~b}$ & $0.800 \mathrm{~b}$ & $0.282 \mathrm{~b}$ & $0.497 \mathrm{~b}$ \\
\hline Bentazon/MCPA & $2.00 \mathrm{~L} \mathrm{ha}^{-1}$ & $0.397 \mathrm{~b}$ & $0.872 b$ & $0.562 \mathrm{~b}$ & $0.770 \mathrm{~b}$ \\
\hline Bentazon/MCPA & $2.50 \mathrm{~L} \mathrm{ha}^{-1}$ & $0.410 \mathrm{~b}$ & $0.593 \mathrm{~b}$ & $0.150 \mathrm{~b}$ & $0.187 \mathrm{~b}$ \\
\hline Bentazon/MCPA & $3.00 \mathrm{~L} \mathrm{ha}^{-1}$ & $0.038 \mathrm{~b}$ & $0.240 \mathrm{~b}$ & $0.277 \mathrm{~b}$ & $0.097 \mathrm{~b}$ \\
\hline Pengendalian manual & & $0.253 \mathrm{~b}$ & $0.270 \mathrm{~b}$ & $0.120 \mathrm{~b}$ & $0.000 \mathrm{~b}$ \\
\hline Kontrol & & $1.617 \mathrm{a}$ & $5.753 \mathrm{a}$ & $10.678 \mathrm{a}$ & $14.440 \mathrm{a}$ \\
\hline
\end{tabular}

Keterangan : Data diolah dengan transformasi $(\mathrm{X}+1)^{1 / 2} ;$ Angka pada kolom yang diikuti huruf sama tidak berbeda nyata pada uji Duncan taraf 5\%

Aplikasi dosis $1.00 \mathrm{~L} \mathrm{ha}^{-1}$ menunjukkan pengendalian gulma yang tidak berbeda nyata dengan aplikasi dosis uji yang lebih tinggi dibandingkan dengan pengendalian manual. Hasil ini menunjukkan bahwa aplikasi herbisida berbahan aktif campuran bentazon dan MCPA pada dosis uji $1.00 \mathrm{~L} \mathrm{ha}^{-1}$ sudah efektif mengendalikan gulma sasaran total di lahan percobaan.

Penggunaan herbisida berbahan aktif bentazon dan MCPA efektif untuk mengendalikan gulma pada padi sawah dan efisien dalam pengusahaan tanaman padi sawah. Efektivitas pengendalian gulma bentazon dan MCPA ditunjukkan dengan persentase rata-rata pengendalian gulma sasaran sebesar $96.2 \%$ yang dibandingkan terhadap perlakuan tanpa penyiangan pada 8 MSA (Tabel 1). Efektivitas pengendalian gulma bentazon dan MCPA tersebut mendekati persen pengendalian gulma dengan pengendalian manual sebesar $100 \%$. Efektivitas pengendalian gulma juga ditunjukkan pada pengendalian gulma per spesies yang secara umum mampu mendekati persen pengendalian gulma manual. Aplikasi dosis rendah $1.501 \mathrm{ha}^{-1}$ diharapkan mencegah pencemaran lingkungan 
pada lahan padi sawah yang mana aplikasi dosis ini memberikan efek fitotoksisitas yang relatif rendah dan menunjukkan performa yang sama dengan pengendalian gulma manual seperti yang dilaporkan Pramono et al (2005) serta Azwir dan Ridwan (2009). Penelitian Kusrini (2005) mengungkapkan bahwa pencemaran lingkungan akibat penggunaan dosis pestisida dan pupuk anorganik tinggi menyebabkan tingkat malformasi traumatik yang tinggi pada beberapa jenis katak konsumsi pada lahan sawah pertanian intensif.

\section{Bobot Kering Gulma Sasaran}

Berdasarkan hasil percobaan didapatkan 5 spesies gulma sasaran dari aplikasi herbisida berbahan aktif campuran bentazon dan MCPA yaitu 2 jenis dari golongan teki-tekian (Fimbristylis miliacea dan Cyperus iria) dan 3 jenis dari golongan gulma berdaun lebar (Alternanthera philoxeroides, Ludwigia octovalvis dan Portulaca oleracea) pada lahan percobaan.

Fimbristylis miliacea (L.) Vahl. Aplikasi herbisida berbahan aktif campuran bentazon dan MCPA dapat mengendalikan gulma spesies Fimbristylis miliacea. Hal tersebut ditunjukkan dengan rendahnya bobot kering biomassa tajuk dan jumlah individu pada semua dosis uji dibandingkan terhadap perlakuan tanpa pengendalian gulma (kontrol). Pengaruh aplikasi herbisida terlihat menurunkan biomassa dan jumlah individu gulma yang tidak berbeda nyata dengan perlakuan pengendalian manual.

Tabel 2. Pengaruh aplikasi herbisida campuran bentazon dan MCPA terhadap gulma Fimbristylis miliacea

\begin{tabular}{lccccc}
\hline \multirow{2}{*}{ Perlakuan } & \multirow{2}{*}{ Dosis } & \multicolumn{2}{c}{ Biomassa $\left(\mathrm{g} / 0.25 \mathrm{~m}^{2}\right)$} & \multicolumn{2}{c}{ Jumlah individu } \\
\cline { 3 - 6 } & & $2 \mathrm{MSA}$ & $4 \mathrm{MSA}$ & $2 \mathrm{MSA}$ & $4 \mathrm{MSA}$ \\
\hline Bentazon/MCPA & $1.00 \mathrm{~L} \mathrm{ha}^{-1}$ & $0.223 \mathrm{~b}$ & $0.462 \mathrm{~b}$ & $8.3 \mathrm{~b}$ & $6.7 \mathrm{~b}$ \\
Bentazon/MCPA & $1.50 \mathrm{~L} \mathrm{ha}^{-1}$ & $0.046 \mathrm{~b}$ & $0.192 \mathrm{~b}$ & $3.8 \mathrm{~b}$ & $12.5 \mathrm{~b}$ \\
Bentazon/MCPA & $2.00 \mathrm{~L} \mathrm{ha}^{-1}$ & $0.247 \mathrm{~b}$ & $0.250 \mathrm{~b}$ & $18.5 \mathrm{~b}$ & $8.2 \mathrm{~b}$ \\
Bentazon/MCPA & $2.50 \mathrm{~L} \mathrm{ha}^{-1}$ & $0.079 \mathrm{~b}$ & $0.152 \mathrm{~b}$ & $5.5 \mathrm{~b}$ & $7.5 \mathrm{~b}$ \\
Bentazon/MCPA & $3.00 \mathrm{~L} \mathrm{ha}^{-1}$ & $0.038 \mathrm{~b}$ & $0.175 \mathrm{~b}$ & $1.3 \mathrm{~b}$ & $2.7 \mathrm{~b}$ \\
Pengendalian manual & & $0.235 \mathrm{~b}$ & $0.122 \mathrm{~b}$ & $52.7 \mathrm{ab}$ & $10.5 \mathrm{~b}$ \\
Kontrol & & $0.912 \mathrm{a}$ & $3.250 \mathrm{a}$ & $107.7 \mathrm{a}$ & $77.8 \mathrm{a}$ \\
\hline
\end{tabular}

Keterangan: Data biomassa diolah dengan transformasi $(\mathrm{X}+1)^{1 / 2}$; Data jumlah individu diolah dengan transformasi log $(\mathrm{X}+3)$; Angka pada kolom yang diikuti huruf sama tidak berbeda nyata pada uji Duncan taraf $5 \%$

Aplikasi herbisida berbahan aktif campuran bentazon dan MCPA pada semua dosis uji menunjukkan pengaruh pengendalian bobot kering biomassa dan jumlah individu gulma yang lebih rendah dibandingkan terhadap perlakuan tanpa penyiangan. Aplikasi pada dosis rendah $1.00 \mathrm{~L} \mathrm{ha}^{-1}$ menunjukkan hasil yang tidak berbeda nyata dengan dosis uji yang lebih tinggi. Hasil ini menunjukkan bahwa aplikasi herbisida berbahan aktif bentazon dan MCPA pada dosis rendah 1.00 $\mathrm{L} \mathrm{ha}^{-1}$ sudah efektif untuk mengendalikan gulma Fimbristylis miliacea (L.) Vahl.
Portulaca oleracea L. Aplikasi herbisida berbahan aktif campuran bentazon dan MCPA dapat mengendalikan gulma spesies Portulaca oleracea L. Pengaruh pengendalian bentazon dan MCPA terlihat menurunkan bobot kering biomassa tajuk dan jumlah individu gulma dibandingkan terhadap perlakuan pengendalian manual dan kontrol. Pengaruh aplikasi herbisida terhadap pengendalian gulma pada umur 4 MSA terlihat menurun dibandingkan dengan pengaruh pengendalian gulma 2 MSA (Tabel 3).

Tabel 3. Pengaruh aplikasi herbisida campuran bentazon danMCPA terhadap gulma Portulaca oleracea

\begin{tabular}{|c|c|c|c|c|c|}
\hline \multirow[t]{2}{*}{ Perlakuan } & \multirow[t]{2}{*}{ Dosis } & \multicolumn{2}{|c|}{ Biomassa $\left(\mathrm{g} / 0.25 \mathrm{~m}^{2}\right)$} & \multicolumn{2}{|c|}{ Jumlah individu } \\
\hline & & $2 \mathrm{MSA}$ & $4 \mathrm{MSA}$ & $2 \mathrm{MSA}$ & 4 MSA \\
\hline Bentazon/MCPA & $1.00 \mathrm{~L} \mathrm{ha}^{-1}$ & $0.077 \mathrm{c}$ & $0.195 \mathrm{bc}$ & $1.8 \mathrm{bc}$ & $3.0 \mathrm{ab}$ \\
\hline Bentazon/MCPA & $1.50 \mathrm{~L} \mathrm{ha}^{-1}$ & $0.180 \mathrm{bc}$ & $0.433 \mathrm{ab}$ & $4.7 \mathrm{abc}$ & $6.7 \mathrm{a}$ \\
\hline Bentazon/MCPA & $2.00 \mathrm{~L} \mathrm{ha}^{-1}$ & $0.130 \mathrm{c}$ & $0.522 \mathrm{ab}$ & $3.0 \mathrm{ab}$ & $6.0 \mathrm{a}$ \\
\hline Bentazon/MCPA & $2.50 \mathrm{~L} \mathrm{ha}^{-1}$ & $0.320 \mathrm{~b}$ & $0.040 \mathrm{c}$ & $3.7 \mathrm{ab}$ & $1.0 \mathrm{ab}$ \\
\hline Bentazon/MCPA & $3.00 \mathrm{~L} \mathrm{ha}^{-1}$ & $0.000 \mathrm{~b}$ & $0.013 \mathrm{c}$ & $0.0 \mathrm{~b}$ & $0.2 \mathrm{~b}$ \\
\hline Pengendalian manual & & $0.017 \mathrm{c}$ & $0.035 \mathrm{c}$ & $4.5 \mathrm{abc}$ & $2.5 \mathrm{ab}$ \\
\hline Kontrol & & $0.572 \mathrm{a}$ & $0.633 \mathrm{a}$ & $10.0 \mathrm{a}$ & $10.2 \mathrm{a}$ \\
\hline
\end{tabular}

Keterangan: $\quad$ Data biomassa diolah dengan transformasi $(\mathrm{X}+1)^{1 / 2}$; Data jumlah individu diolah dengan transformasi log $(\mathrm{X}+3)$; Angka pada kolom yang diikuti huruf sama tidak berbeda nyata pada uji Duncan taraf $5 \%$ 
Aplikasi herbisida campuran bentazon dan MCPA mampu mengendalikan biomassa dan jumlah individu gulma yang berbeda nyata dengan perlakuan tanpa penyiangan (kontrol). Aplikasi dosis $2.50-3.00 \mathrm{~L} \mathrm{ha}^{-1}$ menurunkan rata-rata bobot biomassa dan jumlah gulma lebih tinggi dibandingkan dengan dosis uji lain sejak 2 MSA dibandingkan terhadap perlakuan kontrol namun tidak berbeda nyata dengan dosis rendah $1.00 \mathrm{~L}$ $\mathrm{ha}^{-1}$ dan pengendalian gulma manual. Hasil ini menunjukkan dosis aplikasi $1.00 \mathrm{~L} \mathrm{ha}^{-1}$ sudah efektif untuk mengendalikan gulma Portulaca oleracea $\mathrm{L}$.

Alternanthera philoxeroides (Mart.) Griseb. Aplikasi herbisida berbahan aktif campuran bentazon dan MCPA dapat mengendalikan gulma spesies Alternanthera philoxeroides ditandai dengan penurunan biomassa tajuk dan jumlah individu gulma dibandingkan terhadap perlakuan pengendalian manual dan kontrol. Pengaruh aplikasi bentazon dan MCPA pada semua dosis uji menunjukkan pengendalian biomassa dan jumlah individu gulma yang berbeda nyata dengan perlakuan tanpa penyiangan namun tidak berbeda nyata dibandingkan terhadap perlakuan pengendalian manual. Aplikasi herbisida sudah menunjukkan pengaruh pengendalian sejak 6 MSA namun baru berbeda nyata signifikan pada 8 MSA dibandingkan terhadap perlakuan kontrol (Tabel 4).

Dosis uji $1.00 \mathrm{~L}^{-1}$ menunjukkan pengaruh pengendalian gulma yang tidak berbeda nyata dengan dosis uji yang lebih tinggi (1.50 3.00 $\mathrm{L} \mathrm{ha}^{-1}$ ) maupun dibandingkan terhadap pengendalian manual. Pengaruh pengendalian herbisida campuran bentazon dan MCPA ditunjukkan dengan rendahnya bobot biomassa tajuk dan jumlah individu gulma pada seluruh dosis uji dibandingkan terhadap perlakuan kontrol. Hasil tersebut menunjukkan bahwa dosis aplikasi $1.00 \mathrm{~L} \quad$ ha $^{-1}$ sudah efektif untuk mengendalikan gulma Alternanthera philoxeroides (Mart.) Griseb.

Tabel 4. Pengaruh aplikasi herbisida campuran bentazon dan MCPA terhadap gulma Alternanthera philoxeroides

\begin{tabular}{llllcc}
\hline \multirow{2}{*}{ Perlakuan } & \multirow{2}{*}{ Dosis } & \multicolumn{2}{c}{ Biomassa $\left(\mathrm{g} / 0.25 \mathrm{~m}^{2}\right)$} & \multicolumn{2}{c}{ Jumlah individu } \\
\cline { 3 - 5 } & & $6 \mathrm{MSA}$ & $8 \mathrm{MSA}$ & $6 \mathrm{MSA}$ & $8 \mathrm{MSA}$ \\
\hline Bentazon/MCPA & $1.00 \mathrm{~L} \mathrm{ha}^{-1}$ & $0.016 \mathrm{~b}$ & $0.130 \mathrm{~b}$ & $0.3 \mathrm{a}$ & $1.2 \mathrm{~b}$ \\
Bentazon/MCPA & $1.50 \mathrm{~L} \mathrm{ha}^{-1}$ & $0.067 \mathrm{ab}$ & $0.318 \mathrm{~b}$ & $1.2 \mathrm{a}$ & $1.2 \mathrm{~b}$ \\
Bentazon/MCPA & $2.00 \mathrm{~L} \mathrm{ha}^{-1}$ & $0.010 \mathrm{~b}$ & $0.688 \mathrm{~b}$ & $0.3 \mathrm{a}$ & $1.0 \mathrm{~b}$ \\
Bentazon/MCPA & $2.50 \mathrm{~L} \mathrm{ha}^{-1}$ & $0.042 \mathrm{ab}$ & $0.168 \mathrm{~b}$ & $0.5 \mathrm{a}$ & $0.7 \mathrm{~b}$ \\
Bentazon/MCPA & $3.00 \mathrm{~L} \mathrm{ha}^{-1}$ & $0.000 \mathrm{~b}$ & $0.097 \mathrm{~b}$ & $0.0 \mathrm{a}$ & $0.7 \mathrm{~b}$ \\
Pengendalian manual & & $0.002 \mathrm{~b}$ & $0.000 \mathrm{~b}$ & $0.5 \mathrm{a}$ & $0.0 \mathrm{~b}$ \\
Kontrol & & $0.240 \mathrm{a}$ & $1.875 \mathrm{a}$ & $1.0 \mathrm{a}$ & $7.7 \mathrm{a}$ \\
\hline
\end{tabular}

Keterangan : Data biomassa diolah dengan transformasi $(\mathrm{X}+1)^{1 / 2}$; Data jumlah individu diolah dengan transformasi log(X+3); Angka pada kolom yang diikuti huruf sama tidak berbeda nyata pada uji Duncan taraf $5 \%$

Ludwigia octovalvis (Jacq.) Raven. Aplikasi herbisida berbahan aktif campuran bentazon dan MCPA dapat mengendalikan gulma spesies Ludwigia octovalvis yang ditunjukkan dengan penurunan bobot biomassa dan jumlah individu gulma dibandingkan terhadap kontrol pada 4 MSA. Selama percobaan berlangsung, gulma ini hanya ditemukan pada umur 4 MSA. Gulma ini tidak ditemukan pada 6 MSA dan 8 MSA pada saat tajuk tanaman padi mulai merapat (Tabel 5). Menurut Santosa (2009) kondisi naungan mampu menurunkan kerapatan gulma akibat kematian propagul gulma itu sendiri.

Tabel 5. Pengaruh aplikasi herbisida campuran bentazon dan MCPA terhadap gulma Ludwigia octovalvis

\begin{tabular}{|c|c|c|c|}
\hline \multirow{2}{*}{ Perlakuan } & \multirow{2}{*}{ Dosis } & Biomassa $\left(\mathrm{g} / 0.25 \mathrm{~m}^{2}\right)$ & Jumlah individu \\
\hline & & $4 \mathrm{MSA}$ & $4 \mathrm{MSA}$ \\
\hline Bentazon/MCPA & $1.00 \mathrm{~L} \mathrm{ha}^{-1}$ & $0.017 \mathrm{~b}$ & $0.5 \mathrm{~b}$ \\
\hline Bentazon/MCPA & $1.50 \mathrm{~L} \mathrm{ha}^{-1}$ & $0.032 \mathrm{~b}$ & $0.5 \mathrm{~b}$ \\
\hline Bentazon/MCPA & $2.00 \mathrm{~L} \mathrm{ha}^{-1}$ & $0.033 \mathrm{~b}$ & $0.2 \mathrm{~b}$ \\
\hline Bentazon/MCPA & $2.50 \mathrm{~L} \mathrm{ha}^{-1}$ & $0.017 \mathrm{~b}$ & $0.3 \mathrm{~b}$ \\
\hline Bentazon/MCPA & $3.00 \mathrm{~L} \mathrm{ha}^{-1}$ & $0.000 \mathrm{~b}$ & $0.2 \mathrm{~b}$ \\
\hline Pengendalian manual & & $0.032 \mathrm{~b}$ & $0.0 \mathrm{~b}$ \\
\hline Kontrol & & $0.337 \mathrm{a}$ & $2.8 \mathrm{a}$ \\
\hline
\end{tabular}


Pengaruh pengendalian gulma aplikasi herbisida berbahan aktif campuran bentazon dan MCPA ditunjukkan dengan rendahnya bobot kering biomassa dan jumlah gulma pada semua dosis uji dibandingkan terhadap perlakuan kontrol. Aplikasi herbisida campuran bentazon dan MCPA dosis rendah $1.00 \mathrm{~L} \mathrm{ha}^{-1}$ menunjukkan hasil pengendalian gulma yang tidak berbeda nyata dibandingkan dengan dosis yang lebih tinggi maupun perlakuan pengendalian manual. Berdasarkan hasil tersebut aplikasi dosis $1.00 \mathrm{~L}$ ha $^{-1}$ sudah efektif mengendalikan gulma Ludwigia octovalvis (Tabel 5).

Cyperus iria L. Aplikasi herbisida berbahan aktif campuran bentazon dan MCPA mampu mengendalikan gulma spesies Cyperus iria $\mathrm{L}$ yang ditunjukkan dengan penurunan bobot biomassa dan jumlah individu gulma dibandingkan terhadap perlakuan tanpa pengendalian gulma (kontrol). Pengaruh aplikasi terlihat dari rendahnya bobot kering biomassa dan jumlah individu gulma pada semua dosis uji dibandingkan terhadap perlakuan kontrol (Tabel 6).

Aplikasi herbisida berbahan aktif campuran bentazon dan MCPA berpengaruh nyata menurunkan bobot kering biomassa dan jumlah gulma dibandingkan terhadap perlakuan kontrol. Aplikasi dosis rendah $1.00 \mathrm{~L} \mathrm{ha}^{-1}$ menunjukkan pengaruh yang tidak berbeda nyata dibandingkan dengan dosis yang lebih tinggi maupun pengendalian gulma secara manual. Berdasarkan hasil tersebut didapatkan bahwa aplikasi herbisida dosis $1.00 \mathrm{~L} \mathrm{ha}^{-1}$ sudah efektif mengendalikan gulma Cyperus iria.

Tabel 6. Pengaruh aplikasi herbisida campuran bentazon dan MCPA terhadap gulma Cyperus iria

\begin{tabular}{lccccc}
\hline \multirow{2}{*}{ Perlakuan } & \multirow{2}{*}{ Dosis } & \multicolumn{2}{c}{ Biomassa $\left(\mathrm{g} / 0.25 \mathrm{~m}^{2}\right)$} & \multicolumn{2}{c}{ Jumlah individu } \\
\cline { 3 - 5 } & & $2 \mathrm{MSA}$ & $4 \mathrm{MSA}$ & $2 \mathrm{MSA}$ & $4 \mathrm{MSA}$ \\
\hline Bentazon/MCPA & $1.00 \mathrm{~L} \mathrm{ha}^{-1}$ & $0.022 \mathrm{~b}$ & $0.350 \mathrm{~b}$ & $0.2 \mathrm{~b}$ & $2.3 \mathrm{~b}$ \\
Bentazon/MCPA & $1.50 \mathrm{~L} \mathrm{ha}^{-1}$ & $0.000 \mathrm{~b}$ & $0.143 \mathrm{~b}$ & $0.0 \mathrm{~b}$ & $2.2 \mathrm{~b}$ \\
Bentazon/MCPA & $2.00 \mathrm{~L} \mathrm{ha}^{-1}$ & $0.020 \mathrm{~b}$ & $0.067 \mathrm{~b}$ & $0.8 \mathrm{~b}$ & $0.8 \mathrm{~b}$ \\
Bentazon/MCPA & $2.50 \mathrm{~L} \mathrm{ha}^{-1}$ & $0.011 \mathrm{~b}$ & $0.067 \mathrm{~b}$ & $0.3 \mathrm{~b}$ & $0.5 \mathrm{~b}$ \\
Bentazon/MCPA & $3.00 \mathrm{~L} \mathrm{ha}^{-1}$ & $0.000 \mathrm{~b}$ & $0.110 \mathrm{~b}$ & $0.0 \mathrm{~b}$ & $1.2 \mathrm{~b}$ \\
Pengendalian manual & & $0.001 \mathrm{~b}$ & $0.117 \mathrm{~b}$ & $0.3 \mathrm{~b}$ & $1.2 \mathrm{~b}$ \\
Kontrol & & $0.133 \mathrm{a}$ & $1.533 \mathrm{a}$ & $3.0 \mathrm{a}$ & $9.7 \mathrm{a}$
\end{tabular}

Keterangan : Data biomassa diolah dengan transformasi $(\mathrm{X}+1)^{1 / 2}$; Data jumlah individu diolah dengan transformasi log(X+3); Angka pada kolom yang diikuti huruf sama tidak berbeda nyata pada uji Duncan taraf $5 \%$

Aplikasi herbisida berbahan aktif campuran bentazon dan MCPA efektif untuk mengendalikan gulma dari golongan teki dan gulma berdaun lebar dibandingkan terhadap perlakuan tanpa penyiangan gulma serta setara dengan perlakuan pengendalian manual. Hal tersebut ditunjukkan dengan bobot biomassa gulma total yang terlihat lebih rendah secara signifikan jika dibandingkan dengan petak perlakuan kontrol sejak 2 MSA hingga 8 MSA. Dengan kata lain, aplikasi formulasi herbisida ini mampu mengendalikan gulma selama fase vegetatif tanaman padi yaitu sejak umur 3 MST hingga 9 MST. Kedua bahan aktif tersebut menyebabkan gulma tidak dapat membentuk energi yang diperlukan untuk tumbuh yang menyebabkan pertumbuhan gulma terhambat dan atau mati. Menurut DiTomasso (2011), bentazon berperan sebagai herbisida kontak selektif penghambat fotosintesis dengan mengikat elektron dari fotosistem II ke fotosistem I yang menyebabkan tidak terjadinya proses pengikatan ion $\mathrm{H}^{+}$pada fotosistem I oleh $\mathrm{NADP}^{-}$dan pembentukan ATP pada gulma teki dan daun lebar, sedangkan bahan aktif MCPA berperan sebagai herbisida sistemik pada tanah yang mengganggu sistem hormonal pengatur tumbuh gulma daun lebar.

Aplikasi herbisida berbahan aktif campuran bentazon dan MCPA efektif mengendalikan gulma per spesies gulma sasaran dibandingkan terhadap perlakuan kontrol tanpa penyiangan. Gulma $F$. miliacea, $C$. iria, dan $L$. octovalvis efektif terkendalikan pada dosis rendah hingga dosis tinggi, sedangkan spesies gulma $P$. oleracea dan A. philoxeroides lebih terkendalikan pada dosis 2.50-3.00 1 ha $^{-1}$ berturut-turut pada 4 MSA dan 8 MSA dibandingkan dengan perlakuan kontrol tanpa penyiangan gulma. Hasil pengendalian tersebut sejalan dengan penelitian Garrido et al. (1999) yang menyatakan herbisida berbahan aktif campuran bentazon dan MCPA bersifat selektif dan sistemik, serta menurut Fery dan Harrison (2007) menambahkan bahwa kedua bahan aktif tersebut efektif mengendalikan berbagai gulma teki dan beberapa gulma daun lebar.

Aplikasi herbisida berbahan aktif campuran bentazon dan MCPA menunjukkan fitotoksisitas yang rendah pada tanaman budidaya 
selama 2 minggu setelah aplikasi overhead dan meningkat linear dengan peningkatan dosis aplikasi pada pengamatan 2 MSA. Hasil tersebut sejalan dengan beberapa penelitian sebelumnya yang diketahui bahwa toksisitas tanaman budidaya meningkat setiap kenaikan dosis aplikasi selama 2 minggu setelah aplikasi (Garrido et al 1999; Fery dan Harrison 2007; Ceballos et al 2009; Nufarm 2009). Fitotoksisitas rendah terjadi akibat tingginya curah hujan setelah aplikasi yang menyebabkan bahan aktif tercuci oleh air. Gunsolus dan Curran (2002) serta DiTomasso (2011) menjelaskan bahwa bahan aktif bentazon dan MCPA memiliki presistensi selama 14-29 hari namun mudah terlarut dalam air pada curah hujan tinggi. Tercucinya bahan aktif bentazon dan MCPA juga menyebabkan penurunan gejala fitotoksisitas tanaman padi. Hal tersebut ditunjukkan dengan gejala menguningnya bagian tajuk padi sebesar $10-20 \%$ bagian padi pada minggu pertama dan $5-11 \%$ pada minggu kedua setelah aplikasi.

\begin{abstract}
Fitotoksisitas Herbisida. Aplikasi herbisida campuran bentazon dan MCPA menunjukkan adanya fitotoksisitas pada tanaman padi. Gejala keracunan berupa menguningnya tajuk padi yang terjadi pada minggu pertama dan minggu kedua dibandingkan dengan kontrol. Pengamatan visual minggu ketiga tidak menunjukkan adanya indikasi fitotoksisitas pada tanaman padi.
\end{abstract}

Fitotoksisitas aplikasi bentazon dan MCPA nyata terjadi yang ditunjukkan dengan berbeda nyata skor toksisitas dan persen menguningnya tajuk padi dibandingkan terhadap perlakuan pengendalian manual dan kontrol. Aplikasi pada dosis $1.00 \mathrm{~L} \mathrm{ha}^{-1}$ menunjukkan gejala fitotoksisitas yang tidak berbeda nyata dibandingkan dengan dosis yang lebih tinggi. Tingkat keracunan pada minggu kedua terlihat menurun yang ditunjukkan persentase toksisitas tajuk padi yang lebih rendah dibandingkan dengan minggu pertama.

Tabel 7. Toksisitas herbisida campuran bentazon dan MCPA terhadap tanaman padi

\begin{tabular}{|c|c|c|c|c|c|c|c|}
\hline \multirow{2}{*}{ Perlakuan } & \multirow{2}{*}{$\begin{array}{c}\text { Dosis } \\
(\mathrm{L} \text { ha- } 1)\end{array}$} & \multicolumn{2}{|c|}{$1 \mathrm{MSA}$} & \multicolumn{2}{|c|}{$2 \mathrm{MSA}$} & \multicolumn{2}{|c|}{3 MSA } \\
\hline & & Skor $^{b}$ & Persen $(\%)$ & Skor $^{b}$ & Persen $(\%)$ & Skor $^{b}$ & Persen $(\%)$ \\
\hline Bentazon/MCPA & 1.00 & $1.1 \mathrm{a}$ & $10.0 \mathrm{ab}$ & $0.6 \mathrm{a}$ & $5.7 \mathrm{ab}$ & $0.0 \mathrm{a}$ & $0.0 \mathrm{a}$ \\
\hline Bentazon/MCPA & 1.50 & $1.0 \mathrm{a}$ & $8.3 \mathrm{ab}$ & $0.7 \mathrm{a}$ & $7.7 \mathrm{ab}$ & $0.0 \mathrm{a}$ & $0.0 \mathrm{a}$ \\
\hline Bentazon/MCPA & 2.00 & $1.3 \mathrm{a}$ & $20.3 \mathrm{a}$ & $0.7 \mathrm{a}$ & $7.0 \mathrm{ab}$ & $0.0 \mathrm{a}$ & $0.0 \mathrm{a}$ \\
\hline Bentazon/MCPA & 2.50 & $1.2 \mathrm{a}$ & $13.3 \mathrm{a}$ & $0.8 \mathrm{a}$ & $11.3 \mathrm{a}$ & $0.0 \mathrm{a}$ & $0.0 \mathrm{a}$ \\
\hline Bentazon/MCPA & 3.00 & $1.2 \mathrm{a}$ & $16.0 \mathrm{a}$ & $0.8 \mathrm{a}$ & $9.0 \mathrm{a}$ & $0.0 \mathrm{a}$ & $0.0 \mathrm{a}$ \\
\hline Pengandalian manual & & $0.0 \mathrm{~b}$ & $0.0 \mathrm{~b}$ & $0.0 \mathrm{~b}$ & $0.0 \mathrm{~b}$ & $0.0 \mathrm{a}$ & $0.0 \mathrm{a}$ \\
\hline Kontrol & & $0.0 \mathrm{~b}$ & $0.0 \mathrm{~b}$ & $0.0 \mathrm{~b}$ & $0.0 \mathrm{~b}$ & $0.0 \mathrm{a}$ & $0.0 \mathrm{a}$ \\
\hline
\end{tabular}

Keterangan : Data skor diolah dengan transformasi $(\mathrm{X}+0.5)^{1 / 2}$; Angka pada kolom yang diikuti huruf sama tidak berbeda nyata pada uji Duncan taraf $5 \%$; ${ }^{\text {b }}$ skor toksisitas tajuk: skor 0 (0-5\%), skor 1 (5-20\%), skor 2 (21-50\%), skor 3 (51-75\%), skor $4(75-100 \%)$

\section{Pengaruh Herbisida terhadap Tanaman Padi}

Vegetatif tanaman padi. Aplikasi herbisida berbahan aktif campuran bentazon dan MCPA menunjukkan pengaruh yang tidak berbeda nyata terhadap tinggi padi, nisbah tajuk dengan akar (R$S$ rasio) dan panjang akar padi dibandingkan terhadap perlakuan kontrol maupun perlakuan pengendalian manual namun mampu meningkatkan jumlah anakan, bobot biomassa brangkasan dan indeks luas daun (ILD) tanaman padi dibandingkan terhadap perlakuan kontrol (Tabel 8).

Aplikasi dosis $1.00 \mathrm{~L} \mathrm{ha}^{-1}$ berpengaruh meningkatkan jumlah anakan padi yang berbeda nyata dibandingkan terhadap perlakuan kontrol dan tidak berbeda nyata dengan pengendalian manual. Dosis rendah $1.00 \mathrm{~L} \mathrm{ha}^{-1}$ menunjukkan pengaruh yang tidak berbeda nyata dengan dosis yang lebih tinggi maupun perlakuan pengendalian manual. Hasil ini menunjukkan dosis aplikasi 1.00 $\mathrm{L} \mathrm{ha}^{-1}$ efisien untuk meningkatkan jumlah anakan dan bobot brangkasan tanaman padi.

Aplikasi herbisida berbahan aktif campuran bentazon dan MCPA pada semua dosis uji berpengaruh meningkatkan jumlah anakan dan brangkasan padi dan ILD tetapi tidak mempengaruhi pertumbuhan tinggi, nisbah tajuk dan akar serta panjang akar padi (Tabel 8). Fery dan Harrison (2007) mengungkapkan penggunaan herbisida bentazon mampu meningkatkan bagian dan hasil ekonomis tanaman namun tidak mempengaruhi pertumbuhan tanaman tersebut. Hal tersebut diduga akibat minimnya kompetisi hara antara padi dengan gulma sehingga akar padi berkembang dan menyerap lebih banyak hara sebagai bahan baku fotosintat yang kemudian disimpan pada tiap bulir gabah. Penelitian Ceballos et al (2009) mengungkapkan bahwa bahan aktif bentazon dan MCPA mampu 
meningkatkan daya serap hara akibat minimnya kompetisi akar dengan OPT pada media tumbuh. Dugaan ini diperkuat dengan adanya pengaruh meningkatnya ILD dan bobot brangkasan pada dosis $2.50 \mathrm{~L} \mathrm{ha}^{-1}$ (Tabel 8) yang berbeda nyata dibandingkan dengan perlakuan kontrol namun tidak berbeda nyata dengan pengendalian manual. Gardner et al (1991) mengungkapkan ILD mendekati atau sama dengan lima merupakan indeks optimum untuk tanaman yang mengutamakan berat kering maksimum.

Tabel 8. Pengaruh aplikasi herbisida campuran bentazon dan MCPA terhadap vegetatif tanaman padi

\begin{tabular}{|c|c|c|c|c|c|c|c|}
\hline \multirow{2}{*}{ Perlakuan } & Dosis & Tinggi & Anakan & Brangkasan & R-S Ratio & ILD & Panjang akar \\
\hline & (L ha-1) & $7 \operatorname{MST}(\mathrm{cm})$ & $7 \mathrm{MST}$ & Panen $(\mathrm{g})$ & Panen & $8 \mathrm{MST}$ & Panen $(\mathrm{cm})$ \\
\hline Bentazon/MCPA & 1.00 & $84.35 \mathrm{a}$ & $12.5 \mathrm{a}$ & $37.07 \mathrm{ab}$ & $8.4 \mathrm{a}$ & $3.4 \mathrm{bc}$ & $13.30 \mathrm{a}$ \\
\hline Bentazon/MCPA & 1.50 & $90.71 \mathrm{a}$ & $11.8 \mathrm{ab}$ & $46.75 \mathrm{ab}$ & $11.5 \mathrm{a}$ & $3.0 \mathrm{bc}$ & $12.99 \mathrm{a}$ \\
\hline Bentazon/MCPA & 2.00 & $86.95 \mathrm{a}$ & $11.8 \mathrm{ab}$ & $29.93 \mathrm{~b}$ & $8.7 \mathrm{a}$ & $3.1 \mathrm{bc}$ & $11.79 \mathrm{a}$ \\
\hline Bentazon/MCPA & 2.50 & $89.21 \mathrm{a}$ & $11.8 \mathrm{ab}$ & $47.39 \mathrm{a}$ & $10.5 \mathrm{a}$ & $4.9 \mathrm{a}$ & $14.76 \mathrm{a}$ \\
\hline Bentazon/MCPA & 3.00 & $85.68 \mathrm{a}$ & $11.1 \mathrm{ab}$ & $38.91 \mathrm{ab}$ & $9.4 \mathrm{a}$ & $2.8 \mathrm{c}$ & $14.01 \mathrm{a}$ \\
\hline Pengendalian manual & - & $89.64 \mathrm{a}$ & $11.7 \mathrm{ab}$ & $43.30 \mathrm{ab}$ & $8.4 \mathrm{a}$ & $4.1 \mathrm{ab}$ & $14.86 \mathrm{a}$ \\
\hline Kontrol & - & $82.83 \mathrm{a}$ & $10.2 \mathrm{~b}$ & $38.12 \mathrm{ab}$ & $9.4 \mathrm{a}$ & $3.4 \mathrm{bc}$ & $12.12 \mathrm{a}$ \\
\hline
\end{tabular}

Keterangan : Angka pada kolom yang diikuti huruf sama tidak berbeda nyata pada uji Duncan taraf $5 \%$

Komponen produksi tanaman padi. Aplikasi herbisida berbahan aktif campuran bentazon dan MCPA menunjukkan pengaruh yang tidak berbeda nyata pada jumlah anakan produktif dan jumlah gabah per malai dibandingkan dengan perlakuan kontrol namun berpengaruh nyata pada panjang malai padi. Pengaruh aplikasi herbisida campuran Bentazon dan MCPA pada semua dosis uji meningkatkan rata-rata jumlah anakan produktif padi, panjang malai dan jumlah gabah per malai dibandingkan dengan rata-rata pada perlakuan kontrol (Tabel 9).
Aplikasi dosis uji herbisida bentazon dan MCPA menunjukkan pengaruh yang signifikan terhadap panjang malai dibandingkan terhadap panjang malai perlakuan kontrol. Dosis uji $1.00 \mathrm{~L}$ ha $^{-1}$ menunjukkan pengaruh yang tidak berbeda nyata dengan dosis yang lebih tinggi. Hasil ini menunjukkan aplikasi dosis rendah $1.00 \mathrm{~L} \mathrm{ha}^{-1}$ sudah efisien untuk meningkatkan rata-rata komponen produksi padi yang tidak berbeda nyata dengan pengendalian gulma manual.

Tabel 9. Pengaruh aplikasi herbisida campuran bentazon dan MCPA terhadap komponen produksi tanaman padi $^{\mathrm{a}}$

\begin{tabular}{lcccc}
\hline \multirow{2}{*}{ Perlakuan } & Dosis & \multicolumn{3}{c}{ Komponen produksi per rumpun padi } \\
\cline { 3 - 5 } & $($ L ha-1) & $\begin{array}{c}\text { Anakan } \\
\text { produktif }\end{array}$ & $\begin{array}{c}\text { Panjang } \\
\text { malai }(\mathrm{cm})\end{array}$ & $\begin{array}{c}\text { Gabah per } \\
\text { malai (butir) }\end{array}$ \\
\hline Bentazon/MCPA & 1.00 & $9.2 \mathrm{a}$ & $22.75 \mathrm{ab}$ & $134.9 \mathrm{a}$ \\
Bentazon/MCPA & 1.50 & $9.3 \mathrm{a}$ & $23.62 \mathrm{a}$ & $131.9 \mathrm{a}$ \\
Bentazon/MCPA & 2.00 & $8.9 \mathrm{a}$ & $22.32 \mathrm{ab}$ & $133.9 \mathrm{a}$ \\
Bentazon/MCPA & 2.50 & $9.1 \mathrm{a}$ & $22.83 \mathrm{ab}$ & $123.3 \mathrm{a}$ \\
Bentazon/MCPA & 3.00 & $8.4 \mathrm{a}$ & $22.65 \mathrm{ab}$ & $116.3 \mathrm{a}$ \\
Pengendalian manual & - & $8.7 \mathrm{a}$ & $23.02 \mathrm{ab}$ & $129.9 \mathrm{a}$ \\
Kontrol & - & $7.5 \mathrm{a}$ & $22.03 \mathrm{~b}$ & $111.6 \mathrm{a}$ \\
\hline
\end{tabular}

Keterangan : Angka pada kolom yang diikuti huruf sama tidak berbeda nyata pada uji Duncan taraf $5 \%$

Mutu hasil tanaman padi. Hasil uji statistik menunjukkan aplikasi herbisida berbahan aktif campuran bentazon dan MCPA berpengaruh terhadap persen gabah isi dibandingkan dengan perlakuan tanpa pengendalian gulma (Tabel 10). Aplikasi herbisida berbahan aktif campuran bentazon dan MCPA pada semua dosis uji tidak berpengaruh terhadap bobot 1000 butir gabah dibandingkan terhadap perlakuan pengendalian manual dan kontrol. Dosis rendah $1.00 \mathrm{~L} \mathrm{ha}^{-1}$ menunjukkan pengaruh meningkatkan persen gabah isi yang tidak berbeda nyata dengan dosis yang lebih tinggi dan perlakuan pengendalian manual, namun berbeda nyata terhadap perlakuan kontrol. Dosis uji $1.50-2.00 \mathrm{~L} \mathrm{ha}^{-1}$ mampu meningkatkan persentase pengisian gabah sebesar $13.5 \%$ dibandingkan terhadap perlakuan kontrol. Hasil tersebut menunjukkan bahwa dosis $1.00 \mathrm{~L}$ ha $^{-1}$ sudah efektif untuk meningkatkan mutu hasil tanaman padi.

Gabah Kering Panen (GKP) dan Gabah Kering Giling (GKG). Hasil percobaan menunjukkan adanya pengaruh aplikasi Bentazon 
dan MCPA terhadap bobot gabah kering panen dan bobot gabah kering giling ubinan maupun dugaan produktivitas per hektar dibandingkan perlakuan kontrol. Berdasarkan tabel dugaan hasil produksi didapatkan bahwa aplikasi herbisida
Bentazon dan MCPA pada semua dosis uji mampu meningkatkan produksi gabah dibandingkan dengan perlakuan kontrol dan tidak berbeda nyata dibandingkan terhadap hasil perlakuan pengendalian manual (Tabel 11).

Tabel 10. Pengaruh aplikasi herbisida campuran bentazon dan MCPA terhadap pengisian malai padi ${ }^{\mathrm{a}}$

\begin{tabular}{lcccc}
\hline \multicolumn{1}{c}{ Perlakuan } & $\begin{array}{c}\text { Dosis } \\
(\text { L ha-1) }\end{array}$ & $\begin{array}{c}\text { Gabah isi } \\
\text { per malai }(\%)\end{array}$ & $\begin{array}{c}\text { Gabah hampa } \\
\text { per malai }(\%)\end{array}$ & $\begin{array}{c}\text { Bobot } 1000 \\
\text { butir }(\mathrm{g})\end{array}$ \\
\hline Bentazon/MCPA & 1.00 & $74.65 \mathrm{ab}$ & $25.35 \mathrm{ab}$ & $24.76 \mathrm{a}$ \\
Bentazon/MCPA & 1.50 & $78.99 \mathrm{a}$ & $21.01 \mathrm{~b}$ & $25.30 \mathrm{a}$ \\
Bentazon/MCPA & 2.00 & $78.03 \mathrm{a}$ & $21.97 \mathrm{~b}$ & $24.63 \mathrm{a}$ \\
Bentazon/MCPA & 2.50 & $75.48 \mathrm{ab}$ & $24.52 \mathrm{ab}$ & $25.69 \mathrm{a}$ \\
Bentazon/MCPA & 3.00 & $79.45 \mathrm{a}$ & $20.55 \mathrm{~b}$ & $25.37 \mathrm{a}$ \\
Pengendalian manual & - & $77.90 \mathrm{a}$ & $22.10 \mathrm{~b}$ & $25.99 \mathrm{a}$ \\
Kontrol & - & $68.90 \mathrm{~b}$ & $31.10 \mathrm{a}$ & $25.72 \mathrm{a}$ \\
\hline
\end{tabular}

Keterangan : Angka pada kolom yang diikuti huruf yang sama tidak berbeda nyata pada uji Duncan taraf $5 \%$

Dosis uji $1.50 \mathrm{~L} \mathrm{ha}^{-1}$ meningkatkan hasil GKG sebesar $48.6 \%$ dan berbeda nyata dibandingkan terhadap perlakuan tanpa penyiangan serta tidak berbeda nyata terhadap perlakuan pengendalian manual. Dosis aplikasi $1.00 \mathrm{~L} \mathrm{ha}^{-1}$ menunjukkan pengaruh yang tidak berbeda nyata dengan dosis yang lebih tinggi (1.50-3.00 $\left.\mathrm{L} \mathrm{ha}^{-1}\right)$. Aplikasi herbisida pada dosis $1.00 \mathrm{~L} \mathrm{ha}^{-1}$ sudah dapat meningkatkan hasil panen padi baik pada produksi ubinan per $6.25 \mathrm{~m}^{2}$ maupun dugaan produksi per hektar dibandingkan terhadap hasil panen perlakuan kontrol.

Tabel 11. Pengaruh aplikasi formulasi herbisida Bentazon/MCPA terhadap hasil panen ubinan

\begin{tabular}{|c|c|c|c|c|c|}
\hline \multirow{3}{*}{ Perlakuan } & \multirow{3}{*}{$\begin{array}{c}\text { Dosis } \\
\left(\mathrm{L} \mathrm{ha}^{-1}\right)\end{array}$} & \multicolumn{4}{|c|}{ Bobot kering gabah } \\
\hline & & GKP & GKG & GKP & GKG \\
\hline & & \multicolumn{2}{|c|}{$---\left(\mathrm{kg} / 6.25 \mathrm{~m}^{2}\right)---$} & \multicolumn{2}{|c|}{---(ton/ha)--- } \\
\hline Bentazon/MCPA & 1.00 & $2.87 \mathrm{ab}$ & $2.56 \mathrm{ab}$ & $4.59 \mathrm{ab}$ & $4.09 \mathrm{ab}$ \\
\hline Bentazon/MCPA & 1.50 & $3.55 \mathrm{a}$ & $3.07 \mathrm{a}$ & $5.68 \mathrm{a}$ & $4.92 \mathrm{a}$ \\
\hline Bentazon/MCPA & 2.00 & $3.07 \mathrm{ab}$ & $2.59 \mathrm{ab}$ & $4.91 \mathrm{ab}$ & $4.14 \mathrm{ab}$ \\
\hline Bentazon/MCPA & 2.50 & $2.65 \mathrm{ab}$ & $2.21 \mathrm{ab}$ & $4.24 \mathrm{ab}$ & $3.54 \mathrm{ab}$ \\
\hline Bentazon/MCPA & 3.00 & $2.58 \mathrm{ab}$ & $2.29 \mathrm{ab}$ & $4.13 \mathrm{ab}$ & $3.67 \mathrm{ab}$ \\
\hline Pengendalian manual & - & $3.33 \mathrm{ab}$ & $2.93 \mathrm{ab}$ & $5.33 \mathrm{ab}$ & $4.68 \mathrm{ab}$ \\
\hline Kontrol & - & $2.44 \mathrm{~b}$ & $2.07 \mathrm{~b}$ & $3.91 \mathrm{~b}$ & $3.31 \mathrm{~b}$ \\
\hline
\end{tabular}

Keterangan : Angka pada kolom yang diikuti huruf yang sama tidak berbeda nyata pada uji Duncan taraf $5 \%$

\section{KESIMPULAN}

Aplikasi herbisida berbahan aktif campuran bentazon $\left(400 \mathrm{~g} \mathrm{~L}^{-1}\right)$ dan MCPA $\left(60 \mathrm{~g} \mathrm{~L}^{-1}\right)$ dapat mengendalikan gulma dari golongan gulma teki (sedge) yaitu Fimbristylis miliacea dan Cyperus iria dan gulma berdaun lebar (broadleaf) yaitu Alternanthera philoxeroides, Portulaca oleracea, dan Ludwigia octovalvis. Aplikasi herbisida berbahan aktif campuran bentazon dan MCPA pada dosis $1.00 \mathrm{~L} \mathrm{ha}^{-1}$ sudah efektif untuk mengendalikan gulma sasaran pada lahan percobaan. Peningkatan dosis aplikasi yang lebih tinggi dari $1.00 \mathrm{~L} \mathrm{ha}^{-1}$ tidak nyata meningkatkan hasil pengendalian. Aplikasi herbisida berbahan aktif campuran bentazon dan MCPA menyebabkan fitotoksisitas yang ringan pada tanaman padi dan hanya terjadi selama 2 minggu pengamatan setelah aplikasi. Fitotoksisitas tidak terlihat pada pengamatan 3 minggu setelah aplikasi herbisida. Aplikasi herbisida berbahan aktif campuran bentazon dan MCPA mampu meningkatkan pertumbuhan tanaman padi yang ditunjukkan pada jumlah anakan, bobot biomassa brangkasan, dan ILD padi. Produksi padi pada perlakuan aplikasi herbisida pada dosis $1.50 \mathrm{l} \mathrm{ha}^{-1}$ menunjukkan hasil yang lebih tinggi dibandingkan kontrol dan tidak berbeda dengan hasil perlakuan pengendalian manual yang ditunjukkan dengan peningkatan produktivitas sebesar $48.6 \%$ dibandingkan terhadap tanpa pengendalian gulma. Aplikasi dosis $1.50 \mathrm{l} \mathrm{ha}^{-1}$ direkomendasikan untuk meningkatkan efisiensi produksi dan pengendalian gulma pada pengusahaan padi sawah. 


\section{DAFTAR PUSTAKA}

Agus, F. 2011. Environmental and sustainability issues of Indonesian agriculture. J. Litbang Pertanian 30 (4): 140-147.

Azwir, Ridwan. 2009. Peningkatan produktivitas padi sawah dengan perbaikan teknologi budidaya. Akta Agrosia 12(2): 212-218.

AGPRO. 2013. Material Safety Data Sheet: AGPRO Bentazon Label $500 \mathrm{~g} / \mathrm{L}$. Auckland.

BPS [Balai Pusat Statistik]. 2013. Tanaman Pangan. http://bps.go.id [25 Februari 2014].

Billman, W., S. 2001. Pergeseran komposisi gulma pada beberapa jarak tanam jagung dan beberapa frekuensi pengolahan tanah. J. Pertanian Indonesia 3(1): 25-30

BMKG [Badan Meteorologi Klimatologi dan Geofisika]. 2013. Data iklim bulan September 2012-Januari 2013, Stasiun Klimatologi Dramaga.

Bintari, E., N. 2006. Uji daya hasil galur harapan padi tipe baru (Oryza sativa L.) di dua lokasi: Kabupaten Kendal, Jawa Tengah dan Kabupaten Tanah Datar, Sumatera Barat. Skripsi. Institut Pertanian Bogor, Bogor.

Ceballos, R., Cofre, X., Quiroz, A., Espinoza, N., Palma, G. 2009. Bentazon-MCPA effect on fusarium oxysporum root on trifolium pratense in green house condition. J. Soil Sc. Plant Nutr. 9 (2) : 142-154.

DiTomasso, J., M. 2011. Mode of Action of the Growth Regulator Herbicides. University of California, California.

Fery, R., L., Harrison, Jr, H, S. 2007. The Bentazon Herbicide Tolerance Factor in Bohemian Chili Pepper: potential value for application in plant breeding. Vegetable Report Vol. III. [tersedia di: www.clemson.edu]
Garrido, E, M., Lima, J, L, S., Delerue-Matos, C, M., Brett, A, M, O. 1999. Study of interference of MCPA on the electrochemical determination of bentazon on phytopharmaceutical product. Portugaliae Electronichimica Acta (17): 313-317.

Gardner, F, P., Pearce, R, B., Mitchell, R, L. 1991. Fisiologi Tanaman Budidaya. UI Press, Jakarta.

Gunsolus, J, L., Curran, W, S. 2002. Herbicide Mode of Action and Injury Symptoms. University of Minnesota.

Guntoro, D., Chozin, M, A., Santosa, E., Burhan, A, H. 2009. Kompetisi antara ekotipe Echinochloa crus-galli pada beberapa tingkat populasi dengan padi sawah. J. Agron. Indonesia 37 (3): 202-208.

Hamid, A. 2005. Penentuan jumlah benih padi sebar langsung untuk menekan pertumbuhan gulma. Bul. Teknik Pert. 9 (1): 1-3.

Kusrini, M.D. 2005. Edible frog harvesting in Indonesia: Evaluating its impact and ecological context. PhD Thesis. James Cook University, Towsnville.

Makarim, A, K., Ikhwani. 2010. Yield responses of two rice varieties to agronomic treatments. Indonesian J. Agric. 3 (2): 8186.

NuFarm. 2009. Material Safety Data Sheet: MCPA Ester 600 liquid herbicide.

Pramono, J., Basuki, Widarto. 2005. Upaya peningkatan produktivitas padi sawah melalui pendekatan pengelolaan tanaman dan sumberdaya terpadu. Agrosains 7 (1): $1-6$.

Santosa, E., Zaman, S., Puspitasari, I, D. 2009. Simpanan biji gulma dalam tanah di perkebunan teh pada berbagai tahun pangkas. J. Agron. Indonesia 37 (1) : 4654.

Suhartini, T. 2010. Keragaman karakter morfologis plasma nutfah spesies padi liar (Oryza spp.). Bul. Plasma Nutfah 16 (1) : 17-28. 